\title{
Selected Reference Books of 1964-65
}

\section{INTRODUCTION}

$\mathrm{T}$ HIS ARTICLE continues the semi-annual series ${ }^{1}$ originally edited by Constance M. Winchell. Though it appears under a byline the list is actually a project of the reference department of the Columbia University libraries, and notes are signed with the initials of individual staff members. ${ }^{2}$

Since the purpose of the list is to present a selection of recent scholarly and foreign works of interest to reference workers in university libraries it does not pretend to be either well balanced or comprehensive. Code numbers (such as A11, 1A26, 2S22) have been used to refer to titles in the Guide ${ }^{3}$ and its supplements.

\section{BIBLIOGRAPHY}

Polish Society of Arts and Sciences Abroad. Bibliography of Works by Polish Scholars and Scientists Published Outside Poland in Languages Other Than Polish. Comp. by Maria Danilewicz and Jadwiga Nowak. London, The Society, 1964- . v.1-

Contents: v.1, 1939-1962. 175p. 42s.

While providing a survey of the publications of Polish emigré scholars, the bibliography also serves as a complement to $\mathrm{Za}$ bielska's Bibliography of Books in Polish or Relating to Poland Published Outside Poland . . . (Suppl. 2A65). Entered are detailed citations for both books and periodical articles in all academic fields. These

\footnotetext{
${ }^{1} C R L$, January and July issues starting January, 1952.

2 Evelyn Allen, Adele Combs, Rita Keckeissen, Sarah Ropes, Charlotte Smith.

${ }^{3}$ Constance M. Winchell, Guide to Reference Books (7th ed.: Chicago: ALA, 1951) : Supplement (Chicago: ALA, 1954) ; Second Supplement (Chicago: ALA, 1956) : Third Supplement (Chicago: ALA, 1960); Fourth Supplement (Chicago: ALA, 1963).
}

are grouped by subject and indexed by author (for whom a birth date and country of residence are given whenever ascertainable). An unfortunate omission is a list of the subject headings used and the pages on which they may be found.-E.A.

\section{Periodicals \& Newspapers}

Cumulated Magazine Subject Index, 19071949; a Cumulation of the F. W. Faxon Company's Annual Magazine Subject Index. Boston, G.K. Hall, 1964. 2v. \$490.

By cutting, pasting, and interfiling entries from the forty-three volumes of the Annual Magazine Subject Index (Guide E73), the editors have brought together in one alphabetical sequence all the citations for the 1907-49 period. Long valued as a complement to other standard indexes, and noted for its coverage of local history and certain special areas, the usefulness of the Index is greatly enhanced by this cumulation. As the Guide annotation indicates, coverage for a number of titles includes issues prior to 1907 , and general policy was to include only periodicals not indexed elsewhere.-E.S.

Internationale Bibliographie der Zeitschriftenliteratur aus allen Gebieten des Wissens. Otto Zeller, ed. Osnabrück, F. Dietrich, 1965- . Jahrg. 1- , 1963/64- . $\$ 420$ per yr.

Title also in English and French.

This new international guide to articles in periodicals "covering all fields of knowledge" will replace the old Internationale Bibliographie der Zeitschriftenliteratur (Abt. A, Bibliographie der deutschen Zeitschriftenliteratur, Guide E87, and Abt. B, Bibliographie der fremdsprachigen Zeitschriftenliteratur, Guide E67), merging material formerly separated in Abteilung A (German periodical literature) and Abteilung B (foreign-language material). Frequency is ex- 
pected to be approximately the same, with half-yearly author indexes. While arrangement and format have been changed very little from those of its predecessors, the absence of bold-face type for key words and numerical symbols makes the new index more difficult to scan. A useful difference, however, is that the hitherto exclusively German subject headings now have references from English and French forms. Covering approximately eight thousand periodicals, the new guide has the same wide coverage as the old, and the advantage of having German and non-German material in one alphabet should be considerable.-C.S.

Paris. Bibliothèque Nationale. Département des périodiques. Bibliographie de la presse française politique et d'information générale, 1865-1944. Paris, Bibliothèque $\mathrm{Na}$ tionale, 1964-

Chronologically this new bibliography is a successor to Hatin (Guide E26) and is concerned with political and general news journals, mainly dailies and weeklies. The completed work will comprise four volumes made up of eighty-nine numbered fascicules plus general introduction and alphabetical title index. Each fascicule treats the publications of one département, and includes a prefatory statement, a detailed bibliographical listing (with library locations), and a chronological list of titles. Fascicules have been numbered in alphabetical sequence by name of département and are being issued as completed.-E.S.

U.S. Library of Congress. General Reference and Bibliography Division. Bibliography and Reference Correspondence Section. Union Lists of Serials; a Bibliography. Comp. by Ruth S. Freitag. Washington, 1964. \$1.25.

This annotated bibliography of 1,218 entries brings up to date the Haskell and Brown list which appeared in the Union List of Serials, 2d. ed., 1943. Like its predecessor, the new work includes separately published union lists and those which have appeared as journal articles. Arrangement is geographical, then alphabetic within each section. Descriptive notes give arrangement of the work cited, number and location of libraries, number of serials included, whether holdings are shown, and presence of indexes. Indexes of names, subjects and geographical names add to the work's usefulness.-R.K.

\section{Government Documents}

Poole, Mary Elizabeth. Index to Readex Microprint Edition of JPRS Reports (Joint Publications Research Service). New York, Readex Microprint Corp., [1964]. 137p. $\$ 10$. (Free to subscribers to Readex Microprint Editions of JPRS Reports or U.S. Government Non-Depository Publications.)

The necessary Monthly Catalog dates and entry numbers for locating JPRS reports in the Readex Microprint editions are provided in this index. It is a straight numerical listing by JPRS number, with a separate section at back giving the numbers of JPRS reports not indexed in the Monthly Catalog; no titles or subjects are given. Annual supplements are planned for the present volume which ends with the December 1963 Monthly Catalog listing. The introduction is useful for its explanation of the various JPRS series.-A.C.

\section{RELIGION}

Maryknoll Catholic Dictionary. Comp. and ed. by Albert J. Nevins. [Wilkes-Barre, Pa.], Dimension Books, [1965]. 710p. $\$ 9.95$.

In addition to offering definitions of standard Catholic words and terms, the dictionary attempts "to mirror movements and changes" in liturgy and Catholic thinking since the second Vatican Council. Designed to give "clear and accurate explanations rather than strict definitions" while avoiding being "over-technical or encyclopedic" (Introd.), it is not strictly "popular" and should be particularly useful to lay people and non-Catholics. Subjects are not confined to purely religious ones, but include contemporary movements, theories and terminologies as they apply to Catholic life. Intended for use in the United States and Canada, the work gives phonetic pronunciations for foreign words and includes some biographical data on deceased Catholics of both nations. Also included are sections on 
Catholic abbreviations, forms of address, and lists of patron saints and Popes.-C.S.

\section{SOCIAL WORK}

Encyclopedia of Social Work. New York, National Association of Social Workers, 1965- . Issue 15- .

Supersedes the Social Work Year Book, and continues its numbering.

Like its predecessor, this work has signed, topical articles with bibliographies; a directory of international, national and Canadian welfare agencies (voluntary and governmental); a list of periodicals; and an index. The topical section now includes ninety-four biographical sketches of important social workers and social welfare leaders of the past. The "Code of Ethics" and a "Working Definition of Social Work Practice" have been added in the appendix. There is also a new section of forty-five statistical tables with sources. The encyclopedia is to be "issued at regular intervals of perhaps five or ten years." (Pref.)-A.C.

\section{Political Science}

Arms Control and Disarmament; a Quarterly Bibliography with Abstracts and Annotations. v.1, no.1- , Winter 1964/65Washington, G.P.O., 1964- . \$2 per yr.

With the support of the U.S. Arms Control and Disarmament Agency this new quarterly has been compiled by the Arms Control and Disarmament Bibliography Section of the Library of Congress. Items are "selected from a survey of the literature received by the Library of Congress that is likely to be available in the larger research and public libraries in the United States" (Pref.), and listings include abstracts or brief annotations of books, periodical articles, government documents, and publications of international organizations. After the first number (which includes some important materials from mid-1964) each issue will concentrate on materials published in the three-month period prior to press time. A classed arrangement with author index is used, and there will be a subject and a cumulated author index in the fourth number.-E.S.
Back, Harry, Cirullies, Horst, and Marquard, Günter. Polec: Dictionary of Politics and Economics; Dictionnaire de politique et d'économie; Wörterbuch für Politik und Wirtschaft. Berlin, W. de Gruyter, 1964. 961p. DM 38 .

English, French, and German terms in politics and economics, plus some words and phrases from modern technology are presented in a single alphabet. Definition is given in the language of the term itself, and equivalents in the other two languages are indicated if they exist. If the term is spelled the same in all three languages (e.g., Latin words and phrases) definitions are given in each of the languages under a single entry. Symbols are used in the text to refer the reader to related entries. The editors have drawn on their experience as journalists and translators in the selection of terms for inclusion.-E.S.

Haensch, Günther. Wörterbuch der internationalen Beziehungen und der Politik. Systematisch und alphabetisch. DeutschEnglisch-Französisch-Spanisch. Dictionary of International Relations and Politics [etc.]. Munich, Max Hueber Verlag, 1965. 638p. $\$ 8.70$.

Title in German, English, French and Spanish.

Readers of foreign-language materials on international affairs will surely be pleased with the scope and format of this one-volume multilingual dictionary of the basic vocabulary in the field. Grouped by subject, the words, phrases, and geographical names can be approached collectively through the detailed table of contents or individually through the alphabetical index. Both are quatrolingual. The preface stresses that geographical differences in usage are accounted for.-E.A.

Russett, Bruce M. [et al.]. World Handbook of Political and Social Indicators. New Haven, Yale University Press, 1964. 373p. $\$ 10$.

Intended as an aid to sociologists and economists as well as to political scientists, the Handbook represents "an attempt to compare nations on a great variety of politically relevant indices." (Pref.) Part A, 
"Distribution Profiles" provides tables, with explanatory notes, on seventy-five series of data for all countries for which "reasonably reliable information" was obtainable. Countries are ranked from highest to lowest on each scale, and a simple statistical summary is presented. Tables are grouped under such headings as "Human Resources," "Wealth," "Education" and range over topics like "Votes in National Elections as a Percentage of Voting-Age Population," "Emigrants per 1,000 Population," and "Cinema Attendance per Capita." Part B offers an "Analysis of Trends and Patterns."-E.S.

\section{ECONOMICS}

\section{McGraw-Hill Dictionary of Modern Eco-} nomics; a Handbook of Terms and Organizations by Douglas Greenwald and others. New York, McGraw-Hill, 1965. 697 p. $\$ 14.75$.

Definitions, usually not exceeding four hundred words, of approximately one thousand three hundred modern economic and related terms are alphabetically arranged in Part I of this dictionary. The terms were selected and defined by seven economists who are past and present members of the department of economics of McGraw-Hill Publications. Definitions were written for the reader with no previous knowledge of the subject. Original and current sources of information are given for most of the terms, and, where applicable, sources of economic data are provided. Some definitions are supplemented by charts, tables, and diagrams. Part II alphabetically lists and describes two hundred private and public organizations concerned with economics and marketing. The organizations' major publications are included in most of these descriptions.A.C.

\section{DiCTIONARIES}

Blachère, Régis, Chouémi, Moustafa, and Denizeau, Claude. Dictionnaire arabefrançais-anglais (Langue classique et moderne). Arabic/French/English Dictionary.

Paris, G. P. Maisonneuve et Larose, 1964-

$$
\text { . v.1, fasc.1- . (In progress) }
$$

Generally speaking, Arabic vocabulary has been scattered in glossaries and lexicons which cover only a single period. The intent of this new dictionary is to gather all the vocabulary that comprises "literary" Arabic from the latter half of the sixth century to the present day. "Literary" Arabic is here defined as the vocabulary of writers, journalists, orators, and university circles; idiomatic elements have been excluded, but the editors have tried to be flexible in their selection. Place names of historical importance have been included. The work was compiled through the examination of existing dictionaries, the Koran, and representative authors of various periods. References have been made to these sources only for the Koran and for rare or difficult meanings. Definitions are given in French, then English. The first fascicule includes a transcription table, lists of abbreviations, and of sources cited as references.-S.R.

Houaiss, Antonio, and Avery, Catherine B. The New Appleton Dictionary of the English and Portuguese Languages. New York, Appleton-Century-Crofts, 1964. 636, 665p. \$11.75.

Added title page in Portuguese.

Emphasis is on "Portuguese as it is spoken and written in Brazil" (Pref.) in this valuable new dictionary. The work is in two parts, English-Portuguese and PortugueseEnglish, each including about sixty thousand words and phrases with their equivalents in the other language (though, owing to geographic differences, etc., the two word lists are not completely reversible). Range of vocabulary is broad, with numerous terms drawn from specialized fields. Phonetic pronunciation is shown in both parts, with cultivated Brazilian speech serving as the basis for the Portuguese pronunciations.-E.S.

\section{DANCE}

Raffé, W. G., ed. Dictionary of the Dance. New York, A. S. Barnes and Co., 1964. 583p. $\$ 20$.

Stating its aim as "to rediscover original meanings of rhythmic movement" (Foreword), this dictionary should be of interest to the general reader and the scholar in many fields. Fairly short articles offer historical and descriptive information about many specific dances, a variety of subjects relating to the dance, and some very general topics such as "Japanese Dances." No entries are made for individual dancers and 
choreographers. There is a general bibliography at the end, followed by a useful geographic index listing dances by country of origin.-S.R.

\section{Music}

Duckles, Vincent Harris. Music Reference and Research Materials; an Annotated Bibliography. New York, Free Press, [1964]. 331p. \$5.

This is an expanded, up-to-date, annotated edition of the compiler's Guide to Reference Materials on Music (1949, etc.). Like its predecessors, it is intended to fulfill the requirements of both graduate students doing advanced research and music reference librarians in large research libraries. As "a bibliography of music bibliographies" it is not a basic list of titles, but "a list from which essential materials for music reference collections can be selected." (Introd.) As such, there are no entries for biography, local histories, monographs, or studies of the usual subject areas into which music is divided; only in the "Histories and Chronologies" category are books listed for what they contain intrinsically rather than for their function as guides. Peripheral resources (theater, arts, liturgics, etc.) not pertaining exclusively to music are also omitted. Emphasis is on dictionaries and encyclopedias, catalogs of major music libraries and collections throughout the world, guides to methods of research in musicology, and bibliographies of music literature.-C.S.

\section{LITERATURE \& LANGUAGE}

Bibliographie zur antiken Bildersprache; unter Leitung von Viktor Pöschl, bearb. von Helga Gärtner und Waltraut Heyke. Heidelberg, C. Winter, 1964. 674p. (Bibliothek der klassischen Altertumswissenschaften. n.f., 1, Reihe.)

Scholarly studies of metaphor, imagery, similie, and allegory in the writings of Greek and Latin classical authors, the Church Fathers, and in the Old and New Testaments and the apocrypha are the subject of this bibliography. There are two principal sections: one arranged by classical author's name (and preceded by a general section of relevant works on literary history, mythology, philosophy, etc.), the other arranged by the words and phrases figuring in the metaphor or imagery. Full citations to books and periodicals are given in the first section; the second provides precise see references to citations in the first. Throughout there are numerous see also references to related articles or terms. There is an index of modern authors and a table of abbreviations. The volume should save the scholar hours of searching through L'Année Philologique and similar bibliographies.E.S.

Bibliography of Old Norse-Icelandic Studies. Copenhagen, Munksgaard, 1964v.1- , 1963- . \$3 per yr.

To fill a gap in Old Norse bibliography, a group of Scandinavian librarians and philologists canvassed scholars for information on their recent publications in the area of Old Norse language and literature, medieval Norwegian and Icelandic history, and related subjects. The first issue of their selective annual bibliography contains 333 listings of books, reviews, and articles from some seventy periodicals in all languages. The arrangement is alphabetical by author with a subject index, but the annotations, if present at all, are extremely brief, indicating only the subject of the article in a word or two or that it is a review. An interesting feature is the introduction: a description of the early development of West Norse literature.-S.R.

Damon, Samuel Foster. A Blake Dictionary; the Ideas and Symbols of William Blake. Providence, R.I., Brown University Press, 1965. 460p. $\$ 15$.

Words, phrases and proper names having a particular symbolic meaning in Blake's poetry and philosophy are explained in specific contexts and in relation to other appearances throughout the Blake canon. All Biblical characters have been included, but not the names of other historical figures or nouns which have no special symbolic significance in Blake's works.-E.S.

Fredeman, William E. Pre-Raphaelitism; $a$ Bibliocritical Study. Cambridge, Harvard University Press, 1965.327 p. $\$ 9.95$.

Few bibliographies, however useful, are as interesting in themselves as this one "covering all aspects of literary and visual Pre- 
Raphaelitism." (Pref.) An introductory essay surveying trends, achievements, and shortcomings in Pre-Raphaelite scholarship is followed by the bibliography proper. This is divided into one hundred sections listing selected critical studies of the individual major and minor figures, associates, and affiliates of the movement. Included also are sections on the description of important public and private collections of PreRaphaelite materials; catalogs of collections of paintings and exhibitions; specific aspects of the movement; and Pre-Raphaelite illustrations. Some entries appear in more than one section; most are annotated; and there is a detailed index.-E.S.

Preminger, Alex, ed. Encyclopedia of Poetry and Poetics. Princeton, Princeton University Press, 1965. 906p. \$20.

Compiled by scholars, this comprehensive work is an alphabetical arrangement of about a thousand entries which range in length from twenty to twenty thousand words and deal with "the history, theory, technique and criticism of poetry from the earliest times to the present." (Pref.) In addition to articles proper to the subjectterminology of poetry, types and schools of poetry and criticism-areas common to prose and poetry (plot, myth, etc.) are included, as are entries which illustrate the relationship of poetry to other fields (e.g., Platonism and poetry, society and poetry). Entries for individual authors and poems have been excluded. Articles carry bibliographies, incorporate many citations, employ frequent cross references, and usually embody some critical evaluation. The list of contributors is given, and articles are signed with initials.-R.K.

Svenskt litteraturlexikon. Lund, C. W. K. Gleerup, [1964]. 620p. Sw. Kr 75.

Biographical sketches of Swedish authors together with articles (ranging from a few lines to several columns) on literary terms make up this handbook. The longer entries are signed with the initials of contributors; some carry bibliographies. There is an index of selected titles of literary works figuring in the text.-E.S.

Tezla, Albert. An Introductory Bibliography to the Study of Hungarian Literature.
Cambridge, Harvard University Press, 1964. 290p. $\$ 10$.

In order to facilitate study and thereby encourage the beginning student, Dr. Tezla has sought to provide a guide to Hungarian literary studies. For the first such guide in this field 1205 primary and secondary sources published through 1960 were selected, examined, and annotated. Primary sources cited include anthologies and series containing selected authors' writings, as well as separate editions of the works of 101 individual authors. Although the title emphasizes the literary aspect of the bibliography, material is included from "all areas of knowledge required by the work of the literary historian." Therefore the category of secondary sources includes reference works and historical-cultural materials both in Hungarian and foreign languages in addition to purely literary materials.

Because good collections of Hungarian materials are scarce, the author has described the ampler ones in his introduction. $\mathrm{He}$ has also provided location symbols for selected United States and European libraries with the citations. An added list of abbreviations, symbols, and Hungarian bibliographical and literary terms with their English equivalents completes what should be a model to compilers of similar guides.E.A.

\section{BIOGRAPHY}

Lewytzyki, Borys and Müller, Kurt. Sowjetische Kurzbiographien. Hannover, Verlag für Literatur und Zeitgeschehen, [1964]. 352p. \$10.95.

Primarily based on the author's own file compiled over a period of ten years from the central organs and newspapers of the republics of the USSR, this one-volume guide contains career biographies of the most prominent party and governmental functionaries, as well as of the leaders of nongovernmental organizations. Notables engaged in science and cultural activities are excluded, and are to be listed in a separate work in preparation. The book is in two parts, the first containing the biographies alphabetically arranged by name, the second the membership lists and organization tables of the various central and regional branches, agencies, and committees of 
government and party. October 1, 1963 was the cutoff date for new material in the body of the work, but an appendix updates the information to February 1964. Unfortunately no explanatory list of abbreviations and acronyms used in the text has been included.-E.A.

Sylvestre, Guy, Conron, Brandon and Klinck, Carl F., eds. Canadian Writers/ Ecrivains canadiens. Toronto, Ryerson Press, [1964]. 163p. $\$ 8.50$.

An "alphabetically arranged handbook of information concerning approximately three hundred authors and their works" (Introd.), this volume illustrates the bilingual character of Canadian literature in its use of both French and English according to the language of the individual writer described. The work is designed to bring up to date Lorne Pierce's An Outline of Canadian Literature (1927), supplying "biographical and bibliographical information not otherwise readily available to the general reader" (Introd.). Entries include name, dates, biography, principal works with publication dates, short bibliography and often, critical comment. A chronology of Canadian literature precedes the biographical accounts and a list of general works in the field follows.R.K.

\section{Geography}

Norge. Oslo, J. W. Cappelen, [1963]. 4v. $780 \mathrm{Kr}$.

Handsomely produced, this is a geographical encyclopedia and atlas of Norway. Volume 1 contains general articles on climate, population, industry, flora, etc., and descriptions of the country by region. Volumes 2 and 3 comprise a topographically arranged encyclopedia of Norway; volume 4 contains an atlas and extensive index for the set. A large number of excellent photographs, many in color, as well as inset charts and tables illustrate the work.-R.K.

\section{Classical Antiquities}

Pauly, August Friedrich von. Der Kleine Pauly; Lexikon der Antike auf der Grundlage von Pauly's Realencyclopädie der classischen Altertumswissenschaft unter Mitwirkung Zahlreicher Fachgelehrter bearb. u. hrsg. von Konrat Ziegler und Walther Sontheimer. Stuttgart, Alfred Druckenmüller Verlag, 1964- . v.1- . $\$ 28.50$ per v.

Contents: Bd.1, Aachen bis Dichalkon. 1558 cols.

To be in four volumes and promised for completion in late 1967 (somewhat earlier than the proposed completion date for its parent work), the Kleine Pauly offers an abridgement of the great Pauly-Wissowa Realencyclopädie der classischen Altertumswissenschaft (Guide V73). A spot-check of this first volume shows that a high percentage of entries from the larger work is carried over into the concise form. Abridgement of the articles was on the basis of individual requirements of the subject rather than according to any fixed ratio or strict rule. Articles are signed with initials; where relevant, new advances in scholarship are reflected; and bibliographic references have been updated as necessary. The concise Pauly should prove a real boon to libraries unable to afford the larger set.-E.S.

\section{History}

Bibliographie annuelle de lhistoire de France du cinquiéme siècle à 1939. Anneés 1953-54. Paris, Editions du Centre National de la Recherche Scientifique, 1964. 900 p. $70 \mathrm{fr}$.

To fill the gap between the last volume of Caron and Stein's Répertoire (covering 1931; Guide V236) and the 1955 volume of the Bibliographie Annuelle (Suppl. 3V95), the Comité Français des Sciences Historiques plans to issue concurrently with its annual bibliography a new series of retrospective volumes. First to appear is this one for 1953-54, listing some sixteen thousand entries and following the arrangement of the annuals for 1955 to date. The period to be covered is a long one, but it is good to be able to note progress in so worthwhile an undertaking.-E.S.

Haberkern, Eugen and Wallach, Joseph Friedrich. Hilfswörterbuch für Historiker; Mittelalter und Neuzeit. 2.Aufl. Bern, Francke Verlag, 1964. 678p. \$18.75.

Originally published in 1935 , the diction- 
ary has been updated to include historical developments in the USSR, East Germany, and superficially, newly important nations, but retains its emphasis on the historical terminology of Central Europe and those other countries with which Germany has had historic contact. It is geared to the German-speaking reader, with transliterations based on German phonetics and a catchword system used to group definitions. To prevent the work from becoming unwieldy, the compilers have limited themselves to purely historical terminology, excluding tangential materials. For this reason, too, etymologies are given only when necessary for real clarification. The preface states that the dictionary has been designed for the scholar and layman alike, but American users will probably be limited to specialists in Central European history.-E.A.

Hammond, Thomas Taylor. Soviet Foreign Relations and World Communism; $a \mathrm{~S} e$ lected, Annotated Bibliography of 7,000 Books in 30 Languages. Princeton, Princeton University Press, 1965. 1240p. \$25.

As the sub-title indicates, this is an extensive listing (with numerous annotations) of books in many languages, together with the most significant journal and newspaper articles, pamphlets, and doctoral dissertations. Arranged in three main sections (by chronological periods, by individual countries, and by special topic), the publications cited cover four major subject areas: (1) Soviet diplomatic and economic relations with all major countries since 1917; (2) Communist movements throughout the world since 1917; (3) Soviet foreign policy and tactics; and (4) internal developments in all Communist countries except the USSR. There is an index of authors, editors, etc., but none of subjects. While a subject index would add to the book's facility in use as a reference work, the detailed table of contents partially compensates.-C.S.

Horecky, Paul Louis, ed. Russia and the Soviet Union; a Bibliographic Guide to Western-Language Publications. Chicago, University of Chicago Press, [1965]. 473p. \$7.95.

This selective annotated bibliography, with emphasis on recent imprints and English-language materials, is a companion volume to the same editor's useful Basic Russian Publications (1962), the two forming "a rigorously pruned inventory of Russian and western publications in the field of studies on Russia and the USSR." (Introd.) Arrangement is by broad subject field with appropriate subdivision; entry gives full bibliographical information, and annotations are descriptive or analytic.R.K.

Jackson, William Vernon. Library Guide for Brazilian Studies. Pittsburgh, University of Pittsburgh Book Center, 1964. 197p. $\$ 7$.

Employing a general subject arrangement, this useful guide to the major United States research collections of Brazilian materials describes and evaluates the holdings of seventy-four libraries. Summary chapters analyze particular collections as a whole and sketch cooperative projects for collecting current materials. The appendices form a major part of the book. One is an annotated union list of ninety-eight Brazilian periodicals in the humanities and social sciences; others contain breakdowns of the Library of Congress classifications for Brazilian history and Brazilian literature, and an index of L.C. classification numbers for Brazilian materials in all fields. The emphasis throughout is on materials for advanced study and research.-S.R.

\section{The Modern Encylopaedia of Australia and}

New Zealand. Sydney, Horwitz-Grahame, [1964]. 1199p. \&8 15s.

Brief, unsigned articles ranging from a few lines to one or two columns characterize this one-volume encyclopedia. Maps, color plate, and line drawings supplement the text. A concise chronology precedes the main alphabetical section; a "Quick Reference Section" (tables and statistics) and a list of abbreviations follow it. There is no index, but the lists of maps and color plates, and a separate table of contents for the "Quick Reference Section" are aids in locating information. The volume will be most useful for minor topics relating to Australia and New Zealand.-A.C. 